\title{
THE PYGMY MIMIC
}

\author{
Stan Frankland ${ }^{1}$
}

\begin{abstract}
The Pygmy mimic is an extremely persistent colonial trope that continues to inform contemporary anthropological understandings of Africa's Pygmy populations. Mimicry is now understood as being a key component of the social reproduction of a distinct Pygmy way of being. In this paper I examine the historical accounts of mimicry and try to bring a historical perspective to bear on contemporary ethnographic accounts of its practice. I also set my own research among the Sua Pygmies of Uganda against these other examples. The intention behind this is to acknowledge the common humanity of Africa's Pygmies and to create new grounds of comparison - such as a shared history of oppression - that are not dependent on a unique foraging mode of thought.
\end{abstract}

\section{INTRODUCTION}

During the course of his career, the philosopher Kwame Anthony Appiah has occasionally mentioned the work of the anthropologist Colin Turnbull. Perhaps this is not altogether surprising. Turnbull had for a brief period been the general secretary of an organisation called Racial Unity and Appiah's mother had met his father while working for the organisation. Appiah would thus have been familiar with Turnbull's pop ethnography classic The Forest People (1961). He refers briefly to the book in The Ethics of Identity (2005: 150), but makes fuller use of the Mbuti in his introduction to contemporary philosophy Thinking it Through (2003). Elsewhere, Appiah (2000: 55) synthesises what he learnt about the Mbuti from the work of Turnbull:

He uncovered a world where musical creativity, storytelling, playing with children, flirting, dancing, and feasting were shared in small communities where there was no formal power, and ridicule and (usually short-term) ostracism were the only penalties for adult moral failings.

This classic formulation of The Forest People informs Appiah's use of the Mbuti as an ethnographic example in Thinking it Through. For Appiah, the Mbuti are a Rousseauesque contrast to a Hobbesian absolute state. Their life is one of freedom, based on 'a very simple level of material life' (2003: 230). Although members of a

${ }^{1}$ Stan Frankland has worked in the anthropology department at the University of St Andrews from 2002. Since 1994, he has carried out multiple research visits to the Sua in the Semuliki valley in Western Uganda. The most recent was during November/December 2011. 
nation state, the 'traditional' loose-knit society of the Mbuti has no politics. They exist without political organisation, without leaders, and without official sanctions on behaviour. 'Among themselves they live pretty much as they did before there was a modern state around them' (Ibid: 221). In effect, and despite their relative simplicity, Appiah's version of the Mbuti has managed to stay unchanged in the world of change that surrounds them. With their tolerance and altruism, these 'natural' people stand in stark contrast to the supposed positive benefits of civilisation. They are trapped, caught forever in the pre-time of the 'traditional', in Turnbull's romanticised ethnographic permanent.

It is this idea of the eternal Pygmy, of a forever forest-bound consciousness, that I want to explore in further detail. My main concern is how this powerful and persuasive 'ideal type' overshadows the diverse and varied populations that are deemed to make up the Pygmies of Central Africa. The impact of Turnbull's paean to the forest life of the Mbuti has been profound, extending far beyond the disciplinary boundaries of anthropology. Hewlett (1996: 215) has noted, 'no comparable ethnography has come along to replace [it ... and] as a result, most individuals, including anthropologists, view Mbuti culture as synonymous with African Pygmy culture'. Beyond this, as Bahuchet (2014: 3-7) notes, there has been an imbalance in the literature on Pygmies with 86 percent of publications focusing on only five 'forest-oriented' groups ${ }^{1}$ thereby maintaining the stereotype of the 'true Pygmy'. Further than this, there has also been a tendency among researchers - 'Turnbull's syndrome' (Frankland 1999) - to seek out those among those groups that correspond most closely to the hunting and gathering ideal. The consequence of this is that the forest remains the unifying element and that the diversity of ways of being Pygmy remains largely unexplored.

How, for example, can the 3000 or so Batwa and Basua Pygmies in Uganda be described? Of these, none exist solely by hunting and gathering and few if any live within the boundaries of a forest. They clearly do not correspond to the ideal of the forest people. Are they simply a degraded version of the 'pure Pygmy'? Do they lack the resilience of the forest-oriented groups to maintain a seemingly unchanging way of life? The forest-bound Pygmy of anthropological and popular discourse relies on a series of inclusions and exclusions within a very limited understanding of the conditions of their existence. It is a very particular will to a rather partial and biased truth that promotes a reduced representation of the Pygmies. It ignores what Rupp (2014: 296) has called a multiangular perspective, one that 'helps us to appreciate that forest people's experience and express social identities, ethnic affiliations, and even stereotypes in malleable, diverse ways'. More specifically, it delegitimizes the very real experiences and hardships faced by all those Pygmies who do not conform to type.

Following Rupp's suggestion, the aim of this article is to try and redress this imbalance in two parallel ways. Firstly, by combining accounts of early European explorers and contemporary anthropological sources, which are often overlooked in favour of a longue durée of egalitarianism (cf. Moïse 2014), I challenge once again the notion of the eternal Pygmy. . In particular, I focus on the colonial trope of the 
Pygmy mimic and the way it has percolated into contemporary usage. The reason for this is explained through the second thread running through the paper. In this, I offer ethnographic examples that highlight the harsh conditions of existence faced by the Sua of Uganda and by the Mbuti. By revealing a very different understanding of the Pygmy mimic, I try to show the common humanity of Africa's Pygmies. Rather than maintaining their seclusion within the mythical forest, I attempt to create new grounds of comparison, such as a shared history of oppression, that are not dependent on a unique foraging mode of thought. To do this, I begin in Western Uganda and with the Sua.

\section{THE SUA}

It had been an uneventful day in the Bundimasoli resettlement camp, home to close to one hundred BaSua, a small and isolated community among Uganda's marginalised minority of Pygmies. The run-down camp, built at the edge of a vibrant and growing trading centre of the same name, is about one kilometre from the Semuliki National Park in Bundibugyo district, Western Uganda. Close to the border with the Democratic Republic of Congo, the Park encapsulates the Semuliki Forest, the eastern-most extension of the Ituri Forest and home of Colin Turnbull's Forest People. Until the creation of the Park in 1993, the forest had also been home to the Sua, an offshoot of the Efe among the 'archer groups' included in the 'Bambuti cluster' of Africa's Pygmy population. This act of 'conservation' transformed the lives of the Basua. They were denied meaningful access to the forest, at that time still a key resource within their economic system and the basis of their spiritual beliefs. It was also during 1993 that the Adventist Development Relief Agency (ADRA) began a resettlement programme. Threatened with eviction, the Basua had no real alternative other than to agree with the ADRA plan and move from their long-term camps within the Park. For various reasons (cf. Frankland 1999), the money for the scheme ran out and ADRA's programme disintegrated after 18 months. The land had not been bought so the Sua were left effectively landless, becoming what Dowie (2009) has called 'conservation refugees'.

At first, the Sua moved back to the places from which they had been evicted, but by the end of 1995, many of them had moved to temporary dwellings located on the land of the local Adventist community in Bundimasoli, where a school block was being built for them with funding from a Canadian Adventist Church. They returned to the forest edge at Mpulya every day where, although their access was strictly limited, they were allowed to gather basic 'subsistence' resources such as firewood. It also enabled them to wait for the increasing numbers of tourists. Tourism had long been a major part of the Sua's means of subsistence (Frankland 2002) and had mostly replaced the 'foraging mode of production'. The relative peace brought to Uganda since 1986 by the regime of President Museveni had led to a steady growth in tourism to the country. 1996 was the peak year for tourism in the Semuliki valley and it became the main source of income for the Basua. However, this period of abundance was short-lived, coming to an abrupt end with war between the Ugandan government and the Allied Democratic Forces (ADF). 
By 1997, the war had transformed Bundibugyo District. Nearly the entire population had become refugees from the fighting and was gathered in Internally Displaced Peoples (IDP) camps located throughout the valley. The Sua homes in the Adventist compound at Bundimasoli became absorbed within one of these IDP camps and their houses were taken from them. Throughout the course of the war, the Sua lived in 'traditional' shelters just outside the IDP camp. Kirsten Alnaes (2009:116) has described the ravages that this war inflicted upon the people of Bundibugyo in the stark terms of Agamben's 'bare life': 'The rebels created a world ... for the Bundibugyo population in which there was no future, only a present where death stared them in the face.' This was particularly true for the Sua. A number worked with the Ugandan army and one died wearing the uniform of the Uganda Peoples Defense Force (UPDF). Another was killed by the UPDF for being a rebel, and three of them were arrested and tortured on suspicion of the same crime. A generation of elder people died out, many during a cholera outbreak in the IDP camp. It was also during the war that an old myth about Pygmies took on a very modern significance. It had always been said locally that sleeping with a Pygmy woman cured backache. This was because of the supernatural powers that were attributed to them: they were called 'forest ghosts' and many people believed them to be dangerous spirits from a dangerous environment. During the war, this power to cure became transposed onto HIV/AIDS, and the men who believed this medical myth the most were in the UPDF. As a consequence of this and the harsh conditions faced by Sua women during the war, almost all of the younger women at the time became infected and almost all of them are now dead. This caused a huge demographic shift within the population of the Basua. Now, over $50 \%$ of the population is under the age of 15 and a great many of these are 'orphans'. The HIV rate amongst the whole population is extremely high. ${ }^{2}$

By 2002, with the war now ended, the Sua had no option but to return to the forest. Back in Mpulya they lived by the roadside, eking out an existence from forest foraging and some tourism. In a wave of post-civil war redevelopment, which took the Sua as its object, in 2007 they became the recipients of a resettlement project, run by a 'consortium' of 'local' organisations and funded by the European Commission to Uganda. This effort at resettlement moved the Sua back to Bundimasoli, by then a far larger trading centre with a whole different range of residents than before and during the war. ${ }^{3}$

From the very start, the project seemed to be built on shaky foundations, based on little to no actual knowledge of the Sua. After the completion of the barracks style semi-permanent dwellings built to house them, there was very little sign of any other further 'development' taking place on the ground. As the general excitement about the relocation began to fade and efforts to 'empower' the Sua failed to materialise, life returned to the same state of 'poverty' from which they had been supposedly removed. Indeed, the conditions of existence in the resettlement camp seemed to enhance a sense of dependency that had grown since their eviction from the National Park. Waiting for tourists had become a habit since the early 1990s when tourism began to provide the main source of income for the Sua. After the war had finished and the Sua had moved back to Mpulya, tourists' money was even 
more critical. For the men in particular, to miss out on a tourist visit was to risk foregoing a larger financial reward than could be gained through the majority of subsistence strategies. Sitting and waiting was the most profitable way to spend one's time.

This approach continued to be the default position for most Sua after the resettlement project to Bundimasoli had stagnated into inaction and institutional torpor. The 'field officer' attached to the project did little more than act as a tour guide and take a cut of the profits. All formal visitors are called by the generic word bageni, and they are all equally exploitable: from the Europeans who funded the resettlement project to a range of other development practitioners keen to work with the Sua despite the fact that the EU project was already under way. They were all treated as bageni, as were the various researchers, journalists and missionaries that regularly dropped by. Whoever came, the performance by the Sua followed the same pattern, normally concluding with a dance display. Despite the resettlement project, reasons not to sit and wait had become fewer. One phrase often repeated by one of the young men, Kainta, captured the attitude perfectly: 'Let us wait. They will come.'

This was the sense of resignation-with-expectation that prevailed in the camp in the weeks just before Christmas in 2010. Rather like the ADRA scheme before it, the ECfunded resettlement programme had been officially shut down due to serious mismanagement and financial irregularities relating to its implementation. As with the previous resettlement programme, the good intentions that had driven the initial phase of development had faded away and, bar the building of the camp itself, there was little evidence on the ground of any significant positive change in the Sua's hand-to-mouth existence. They remained pauperised, without access to health care and education, and without any long-term, sustainable means of economic survival. Indeed, the move away from the Park edge had made the collection of 'subsistence' materials from the forest a considerably more laborious task. The heavy lifting of firewood and poles combined with the long walk back to the resettlement camp had exacerbated underlying health problems. A number of the Sua had developed hernias as a result of this, and the oldest man in the camp, Ndige, had recently died as a result. Despite the promises of 'development' given to them, they remained without a future.

On the afternoon in question, people sat waiting, clustered in small groups, seeking shade from the sun in the shadows below the corrugated iron roofs of their houses. There had been no bageni, no tourists or other visitors, to disrupt the mundanities of everyday survival and to provide a temporary 'abundance' of cash. It had been a typical post-foraging day for the Sua. Every now and then, gangs of the young children burst across the village, shrieking and laughing as they played one game or another. Occasionally, a neighbour or two from among the multi-ethnic community of Bundimasoli appeared, greeting Sua acquaintances as they passed through. Yet the appearance of inaction was deceptive. A number of Sua had been maintaining a basic income, using a range of economic networks, by providing certain services, some of which were bringing them into conflict with state authorities. For example, 
disputes over their harvesting of various forest products, such as the cutting of poles, reeds and firewood, had caused problems with the Park authorities, and competing interpretations of 'subsistence use' had led to the short-term arrest of many of them. These and other economic services thus required a deal of secrecy: the village, wherever situated within the Semuliki Valley, has always been beyond the law, in no small part due to their exclusion from equal membership within the Ugandan State. As the afternoon dragged on, I noticed a number of people slip discreetly into one or other of the houses to make their covert deals.

These comings and goings continued to punctuate the flow of the day. Some of the women returned from the forest, hauling huge bundles of firewood with straps from around their heads. The sweat glistened on their foreheads and forearms, visible evidence of the strain and effort involved in the task. These bundles would be sold on to other residents within the trading centre for a little less than US\$1. A while later, a group of the men also returned from a different part of the forest where they had been cutting poles for a local businessman. Such deals are commonplace and provide a vital source of disposable cash for the men. Hired as a collective group, the money had been divided equally among them. One or two of them were already sipping from small plastic sachets of Chief waragi, a cheap, strong and popular local brand of gin. A couple of the younger ones had spent their share differently and were chewing mairungi (qhat), a drug that had become increasingly popular among the youth of Bundimasoli over the last few years. As the sun slipped lower in the sky, casting a golden glow over the lower slopes of the Ruwenzori, the Mountains of the Moon, the smell of wood smoke wafted across the resettlement camp. Preparations for the evening meal were underway and women and children gathered close to the fires outside the family dwellings. The men sat by and watched, chewing, drinking and gossiping as they did so.

I was sitting at one end of the camp, outside the house of Nzito, the so-called King of the Batwa (Frankland 2002), when I heard a commotion at the other end of the village. At first, all I could hear was the sound of laughter, but it was then that I saw Tababa strutting across the baked dirt from one cluster of Sua to another. I have known Tababa since he was a young boy and have watched him grow into a confident, humorous and loud young man with a penchant for impersonation. Like some of the other young men, he has remained unmarried and without the resources necessary to maintain a wife. Beyond the collective monies raised through tourism and development, Tababa earned money through physical labour. He had been with the other men cutting poles that afternoon. However, because he was also an extremely fit young man, he also hired himself out individually, pushing barrows of goods for the local traders. Nevertheless, day-to-day existence continued to be a constant struggle, especially with the termination of the European-funded project. Like many of the Sua, he had resorted to selling off the semi-permanent dwelling allocated to him during the resettlement programme. With no reliable longterm means of economic subsistence, the cash realised by selling off the iron sheets for the roof and other reusable materials provided an immediate cash injection. For some, this meant they could pay for urgent medical treatments or settle outstanding debts. However, for Tababa, it meant a brief period of relative affluence in which he 
could create an impression of wealth ${ }^{4}$ and indulge his more carnal needs in the hotspots of Bundimasoli, where sex workers from other regions of Uganda ply their trade.

As Tababa moved his way up the camp to Nzito's place, the reason for the commotion and laughter became clear. He was clearly in high spirits and had, with his new-found affluence, been enjoying the amenities available in the trading centre: its numerous bars, many of them with televisions, often showing music videos from the USA and 'Jamaica'; and its shacks showing a mixture of English Premier League football and films on DVD. With a huge smile on his face, he approached the group of us and then began the performance that had caused such mirth among the other Sua. At first, he began with movements, spinning on his heels and throwing martial arts style shapes and kicks. Each kick and each movement was accompanied by onomatopoeic sound effects, noises he had heard in the video halls of Bundimasoli.

The martial arts he was imitating have grown increasingly popular in Uganda over the last twenty years or so and have even had an impact on contemporary dance styles in Kampala. There is also a ramshackle 'dojo' for Karate in the small town of Bundibugyo, the largest and most populated in the district. For most Ugandans, however, engagement with martial arts comes through the video halls and these films always attract an eager audience. In recent times, a market has emerged for old martial arts films dubbed into Luganda, the main language used in Kampala and one now understood by the majority of the Sua. These dubbed versions tend to be shorter than the original film, frequently cutting out all extraneous material that might detract from the action. Rather than simply translate the original dialogue, these pirate versions provide an overarching meta-commentary on the action unfolding. The voice used is typically loud, deep and aggressively male. It was one of these films that had grabbed Tababa's imagination and provoked him into mimicry. As he spun and kicked out again, he added more than just the sound effects. This time, as he playfully threatened those of us watching, be began to add snippets from the commentary in a suitably gruff voice: 'Chuck Norris .... Colonel ... commando ... Chuck Norris ... commando.' We all knew the film and we all laughed. Two of the other younger men who were sitting with us got up and joined in with Tababa's pantomime, increasing the entertainment value as they did so. The mock fight continued in a whirl of flailing limbs and a succession of 'biff, bang, pows', before finally and inevitability, 'Chuck Norris's' superior skills won the day. Tababa, the mimic, was triumphant.

\section{$\underline{\text { THE PYGMY MIMIC }}$}

The notion of the skilled Pygmy mimic is, of course, not a new one. In his perceptive analysis of the persistent legacies of a colonialist Africanist anthropology on the contemporary discipline, Apter (2007:130) describes the 'diminutive African as mimic and clown' as being a 'typical trope of the time'. In so doing, he cites Seligman's utilisation of an uncontextualised ethnographic example of Pygmy mimicry, drawn in turn from Dr. Wilhelm Junker's account of his 'explorations' of Central Africa. Using Junker's Pygmy as a metonym for the 'imperial palimpsest', 
Apter (2007:133) describes how Seligman's Races of Africa reveals 'an implicit racial logic' that underpinned the colonial and ethnographic 'invention of Africa' (cf. Mudimbe 1988). As such, the Pygmy mimic with his 'sharp powers of observation, amazing talent for mimicry, and a good memory' (Junker 1892:86) and, by extension, Tababa with his explosive Kung Fu commando mime, should not be taken lightly. They require a more considered and contextualized understanding if they are to be anything more than a lingering trope from an uncomfortable anthropological past.

Junker met his unnamed 'Achua' mimic on two occasions. At the first encounter in a trading centre called Rumbek, he subjected the man to his 'anthropometric performance when measuring his body' (Junker 1892:86). It was this scientific objectification that was reincarnated by the mimic when he came across Junker again four years later at another centre, this time in a place called Gambari's. However, it was not only the tools of science that Junker carried with him on his travels. From his description of the 'pigmies', 'the dark goblins of the forest' (Ibid: 79), it is clear that Junker also carried with him the requisite immaterial load of evolutionary and racial anthropological science that befitted such a luminary of African exploration. He compares his perception of the 'Wochua' with the other published accounts of the time that contain descriptions of Pygmies, and he speculates on possible connections between Pygmies and Bushmen. Despite never giving his anthropometric findings, he also describes the Pygmy body in some detail and postulates that Pygmies are not a 'morbid, degenerate people' (Ibid: 85). He goes on to provide some basic ethnographic details about dwellings and the rudimentary lifestyle of the nomadic Pygmies, but perhaps most notably, mentions their desire to 'preserve their freedom intact' (Ibid: 85): their autonomy.

It is clear from Junker's text that he ascribes an acute difference to the Pygmies, a difference that is both racial and evolutionary but also one of 'character'. In this sense, and through his comparative ethnography, he develops a theory of protoprimitive mentality. As such, he is part of the wider colonial process that helped to 'invent' the ethnographic object of the Pygmy. ${ }^{5}$ Through the gradual accretion and tangle of fact and fantasy, of bad science and worse fiction, the mythic figure of the Pygmy began to emerge. The skill of the Pygmy mimic was critical to this pupation. Junker's 'Achua' returns in the accounts of Guy Burrows, a Captain Commandant of the Congo Free State in the 1890s. In his Land of the Pigmies (Burrows 1898:180), he describes a keenness of sight and perception and a 'cultivated quickness' key to the 'hunter's life',. and also highlights the 'good memory' of the Pygmies (Ibid: 181), before repeating Junker's example as a supporting demonstration of this mental acuity. He elaborates:

Mimicry, too, plays a large part in the formation and development of his character, evincing itself not only in his droll humour, but also in the serious facts of his everyday life, for he copies the weapons of his neighbours, and even their habits and customs, where these do not clash with his own (Ibid: 180). 
Here, mimicry is not only a means of humour; it becomes a critical way through which the Pygmy engages with the world. More than that, it becomes a way for him to assimilate external forces on his own terms, maintaining his own unique perspective on the world. So, once again, it is mimicry that helps to facilitate the nomadic, hunting lifestyle as a distinct way of being in the forest. This is the colonial trope magnified, the image of the gnomic comedian playfully mocking the world beyond the forest in an effort to mask his own true identity.

\section{THE FOREST PEOPLE REVISITED}

In a number of ways, this extension of the Pygmy mentality foreshadows the contemporary work by Jerome Lewis $(2008,2008 / 2009,2009,2014)$ on the Mbendjele Pygmies of the northern part of the Republic of Congo. He too uses mimicry as a key enabling function of something that is uniquely and distinctly Pygmy, a complex social process called ekila. Over recent years, Lewis has crafted a highly detailed and sophisticated ethnographic account of the egalitarian social order of the Mbendjele. Building upon the foundations established by Turnbull, he describes how their worldview is comprised of the single social field that is the forest, the 'organic whole, of which people, spirits and animals as well as plants are all a part'. It is the cultural storage device of ekila that sustains and reproduces this 'abundant' ${ }^{6}$ world of sharing (Lewis 2009: 252). Within this context of eco-cultural reproduction, ekila is many things. It is both superstructure and implicit in the experiences of daily life. Ekila is both the minutiae of Mbendjele existence and the cosmological framework in which they exist; it is both the parts and the whole itself. As Lewis (2008: 303) puts it, 'ekila illustrates how ideology and practice influence each other in profound ways'. In the benign and abundant forest, the Mbendjele have a concept of a 'good life', of a proper way of being, of 'good' gender roles, and of correct sharing and appropriate conduct. This is what ekila encourages and promotes, as both a set of rules handed down by those from before (the ancestors) and in the creativity of those who remake them.

It is hard to do justice to the complexity of Lewis's description of this forest-bound ideology and I have no doubt that it encapsulates the world of the Mbendjele to good effect. What is problematic, however, is the way it recreates the notion of the 'pure' forest people, and the consequences this has for understanding other Pygmies like the Mbuti or the Sua. This becomes evident when looking at the 'art-form' of mimicry (Lewis 2009: 246), an important component of ekila, and what Lewis (2014) refers to as the Mbendjele's emic distinction between village and forest worlds. He describes how Mbendjele utilise mimicry as a way maximising the potential outcome of their interactions with neighbouring villagers. 'By playing up to the villagers' arrogant pretensions, claiming pity and speaking in the villagers' tongue' and 'by theatrically mimicking villagers' stereotypes of themselves, Mbendjele get things as safely as possible.' (2009: 239) By enduring humiliation and acting out their own oppression, they treat the villagers as they would an animal to be hunted, as something to be deceived and tricked so as to enable the kill. 
This understanding of Mbendjele/ villager relations is not a new one. Despite a gap of over forty years, it replicates the view put forward by Turnbull (1965: 82) in Wayward Servants where he suggests that the Mbuti 'hunt' the villagers, 'trapping' them within the 'net' of their cunning. Ever the 'ardent pygmyphile' (Beidelman 1996: 275), Turnbull saw the villagers as unwitting dupes lured into a 'false consciousness' (Ibid: 276) by the Mbuti. As such, the villagers were victims of their own assumed superiority and the same 'arrogant pretensions' that Lewis still castigates his villagers for. The single social field of both Mbuti and Mbendjele extends outward only in so much as it is an extension of the tactics employed within the forest. It does not unite the two worlds of the village and forest; rather it maintains them as discrete and wholly separate universes. Central to this division is the 'foraging mode of thought' and the ethos of sharing (Cf. Barnard 2002), the mode of being encapsulated within ekila. By containing all action within this mode of being, the distinction is created between the Pygmy and the world. Kenrick (2005) provides a contemporary update on the Mbuti that shows how this separation works. He focuses on the 'equalizing processes of inclusiveness' (Ibid: 126) that help to maintain the egalitarian lifestyle of the Mbuti. As with ekila, this inclusiveness shapes relations with the forest, the ancestors, each other and their dealings with external agents. Consequently, begging is not a sign of 'poverty'; it is a form of demand sharing (Ibid: 123). Likewise, 'it is more appropriate to see Mbuti responses to tourists, anthropologists, villagers and conservationists, not as happening in a different world to their responses to each other, but as being an extension of the inclusiveness' (Ibid: 124). Despite the fact that Kenrick frames his article around logging and the denigration suffered by the Mbuti, the only option they appear to have is to re-enact 'the equalizing processes of inclusiveness' and remain stuck in a cosmological loop of 'hunter-gatherer situations' (cf. Widlok 2015). Change happens, but the Pygmy mind does not. In this context, mimicry is a critical part of the nature, of the essential properties and relations of being for the forest people, ring fencing them off from anyone else around them.

I propose an alternative scenario, one that is more faithful to the historical and ethnographic record and more appropriate to the Sua and to Tababa's performance. In ethno-archaeological terms, Klieman (2003) suggests that, despite the autochthony of the Batwa, it is impossible to separate them from other forest dwellers. She shows that Batwa and Bantu interactions go back far into the historical record and that any boundaries between them have always been fluid and open to change. Rupp (2011: 93) has also described how the 'histories of the confluences and intermingling' of all the forest dwellers in southeastern Cameroon 'reveal the extent of spatial and social integration among the communities'. Likewise, Grinker (1994) challenges Turnbull's creation of two distinct worlds existing alongside each other and places the Lese and Efe within one single multi-ethnic community. This may well be a community of 'structured inequality', but within it, there are also shared experiences and ways of engaging with the world. Within this context, it is possible to reimagine the encounter between Pygmy and villager as being something more than just another survival skill of the forest. Turnbull himself points unwittingly to another interpretation. He (Turnbull 1965:293) states that he had not met a single villager who had not complained of being 'eaten' by the Mbuti. Here, the use of the 
word 'eaten' resonates strongly with the use of the same word familiar throughout central Africa in the context of corruption and the 'politics of the belly' (cf. Bayart 1993). In this sense, there is the possibility of more options for the Pygmy than the endo-social strategy of maintaining isolation. There is the opportunity of an exosocial intention of incorporation, a way of sharing the same language and the same metaphors with others.

\section{RECOVERING HISTORY}

It is within the dehistoricised world of the forest people that Apter's Pygmy mimic springs back into life as a potent reminder of just what has been obscured through the determination to essentialise a particular and singular mode of Pygmy being. Neither of the two locations in which Junker encountered his mimic were within the boundaries of the rainforest. Rumbek, now in South Sudan, was a notorious staging post on the way to Khartoum for the militarized slave and ivory economies that spread deep into the forest. The second site, in what is now the far eastern part of the Democratic Republic of Congo, was located in the ecological transition zone between forest and savannah environments (Keim 1983). Named after a particularly brutal leader put in place by the slave and ivory traders (Ibid: 9), Gambari's was a key centre for the exploitation and plundering of the region. ${ }^{7}$ Although we can only speculate whether the Pygmy mimic was found in these two particular places through his own wishes or through some form of involuntary servitude, what is certain is that the whole of the Ituri forest region had been through a prolonged period of depredation. The trade in guns, tusks and humans (cf Leopold 2006) had profound consequences not only for the localised niche economies of the area, but also for the security of the diverse peoples within it.

It can be no coincidence that the majority of 'first contact' encounters with Pygmies took place in similar centres of power and commerce. Schweinfurth, one of the key figures in the 'invention of Pygmies', first had contact with the Akka in the court of King Munza of the Mangbetu. The details of this meeting in 1870 are telling and suggest another context for understanding Junker's Pygmy mimic. Schweinfurth (1874: 126) frames the event within a speculation about the ancient origins of 'the dwarf races of Equatorial Africa', drawing a direct connection to the fabled Pygmies of Aristotle. He had already connected these arcane legends with the rumours he had heard of the forest 'dwarfs ... whose fame had so keenly excited [his] curiosity' (Ibid). One morning during his stay within Munza's court, Schweinfurth's attention is broken by a commotion elsewhere in the camp. He (Ibid: 127) then recounts how a man called 'Mohammed had surprised one of the Pygmies in attendance upon the king, and was conveying him, in spite of a strenuous resistance, straight to my tent.' Realising that this may be a unique experience, Schweinfurth 'bribed' a 'royal interpreter' to help him 'pacify' the Akka man. Through gradual inducements, the 'fear' of the man called Adimokoo was allayed and within 'a couple of hours the Pygmy had been measured, sketched, feasted, presented with a variety of gifts and subjected to a minute catechism of searching questions.' (Ibid) 
Within this brief description, Adimokoo is placed within a complex historical and political environment. His Akka are allied to Munza, their camp close to the royal settlement. (Ibid: 67). As such, these Akka are drawn into the expansion of the Mangbetu and Azande 'kingdoms', and a military history going back into the preceding century. The presence of 'Mohammed' and his forceful capture of Adimokoo point to the more recent consequences of the slave and ivory trades, while the struggle to resist and the pacification of the Akka man by Schweinfurth predict an even less secure future under the bloody hands of colonial forces. The limited possibilities of resistance and the very real physical outcomes of subjection shadow the Akka man throughout this encounter. A number of politically charged chronotopes coalesce around this singular event, bringing the past, present and future of Adimokoo to the fore. The single social field of the Akka's forest is not without histories. This produces a very different kind of polyphony to the usual anthropological 'song of the forest', made yet more complex by the inclusion of economic variations as well.

The Akka man's presence in the court situates the foraging mode of production within the context of certain hegemonic relations: patron and client; master and servant; coloniser and colonised. Nothing makes this clearer than a later transaction between the King and the 'explorer' when Munza exchanged a young Akka boy called Nsewue for one of Schweinfurth's dogs. Within the economies of the oppressor, one thing is consistent. The Pygmy is given an economic value: he has a worth within the 'economies of pillage's that shaped the world of the forest. There are, of course, multiple different regional histories of how these pillage economies came to shape the forest world and how they continue to do so today, albeit in very different ways. However, if we are to search for commonalities of experience among Africa's Pygmy populations, it may serve us better to look within the shared histories of oppression than to search for an original state of being. In a manner that set the benchmark for all future engagements between the white world and Africa's Pygmies, Schweinfurth gave gifts as inducements for Adimokoo to perform. In a sense, performance and mimicry were an expected part of the transactional encounter for the Pygmy.

However, this performance of servitude has to be understood within another historical context as well. One aspect of the historical record that is often overlooked is the role of the Pygmies within the warfare that was integral to the success of the pillage economies. Alongside his account of mimicry, Junker also describes the prowess of the Pygmies as both archers and warriors. Because of these warfare skills, they are a people 'much feared ... [and] they are readily engaged by the local chiefs to join in sudden attacks on hostile tribes, and always show themselves willing to perform such services.' (Junker 1892: 85) Gaetano Casati, a former Italian soldier whose journeys through the forest region coincided with those of Junker, Emin Pasha and Stanley, confirms this important relationship. Casati (1989) records that among both the Azande and Mangbetu, rival chiefs would compete for the services of the Akka, bargaining for their skills with arrowheads and food. When paying 'homage' to their employer, 'they perform warlike pantomimes and light and rapid ballets, intermixed with first-rate archery, expressing their thanks for any small gifts 
by salutations and light capers' (Ibid: 110). What is important here is that the Akka are an armed force and that they hire out their services. While the performance of their fierceness is a recognition of their acceptance of other powerful forces, it is also an affirmation of their own agency and value within a highly militarised economy.

Despite the poisoned arrows, booby traps, and ambush strategies, the gun was a powerful enemy. As Casati finally left the great forest with Stanley's relief column, he had one final encounter with the Pygmies. The encounter on May 231889 barely merits a mention in Stanley's (1890: 241) own telling of his heroics, but Casati provides more detail. Having crossed the Semuliki River, the column comes across the deserted camps of the Bassua Pygmies. The response of temporary flight by the Pygmies recurs throughout Stanley's recording of his encounters with them. But later in the day, the Bassua ambushed members of the 'caravan' sent to collect water, surprising them with a volley of arrows. 'They were paid off for their audacity by three of the most daring being shot.' (Casati 1898: 408) Although this act of violence is either ignored or casually dismissed in the texts, this parting shot at the forest by Stanley's brutally invasive force marks the moment of 'first contact' for the Sua ancestors of Tababa. ${ }^{9}$ It is also symbolic of the ultimate pacification of the Pygmies by technologically superior military organisations, their defeat as a force violently resisting and fighting for their existence within an insecure landscape. This pacification process varied due to local and colonial contexts, but the military conquest of the Pygmies should not be forgotten. That these were already a conquered people is evident in another snippet from Casati. In a generous account of his Akka servant, he recalls that among the young man's many laudable qualities, he also used to entertain the column with 'comic dances and somersaults, imitating warlike actions' (Ibid: 421). Gone is the collective affirmation of the Akka military pantomime. In this rather different performance, the Pygmy is the oppressed mimic, his individual war dance reduced to futile, comedic imitation of a power lost. Perhaps it is imputing too much to this dance of the oppressed, but in this instance, the Pygmy mimics his own defeat and dependency. By returning to the historical context of Junker's mimic, I do not mean to say that this is a starting point for the history of Pygmy oppression. Rather, it is one entry point into the past that enables a full recognition of the multiple colonisations suffered both in the past and in the present of the Pygmies.

\section{THE BARE PRESENT}

That these colonisations are still ongoing is evident from a more contemporary example of what could be called Pygmy mimicry. For a brief period from early 2003, Amuzati Nzoli became the most famous Pygmy in the world when international media picked up on accounts of his story that his family had been massacred and cannibalised by soldiers of the Mouvement pour la Libération du Congo (MLC). And in some ways, this 'media' encounter with the world by Amuzati acts as a contemporary rejoinder to the tale of the Pygmy mimic. In jumping from the 19th to the 21st Century, I do not mean to imply that there is that there is one single uninterrupted historical narrative for Africa's Pygmies that unites these two 
moments in time. Each identifiable group of Pygmies has its own singular history based on unique sets of relations and specific localities. However, there are aspects of these that are most definitely shared across the diverse communities. These include the different forms of conquest and domination; that these were resisted in many ways is also not in doubt. There are also the patterns of pacification and the various 'taming policies' ${ }^{10}$ that neutralised and naturalised the Pygmies. These were both directly implemented through governmental policies and church interventions, for example. And they were also indirectly imposed, through representations like those in Turnbull's writings.. Other common themes can also be found: dispossession and landlessness; denigration and exclusion; and commercialisation and exploitation. This list is a brief summary of some components of the Pygmies' shared histories of oppression. This is not to say that life for the forest people is one without any kind of joy. Tababa's Chuck Norris impression is testament to the fact that pleasure can be found even within the conditions of enforced pauperisation. The multifaceted resilience of Africa's Pygmies in the face of ongoing uncertainties is another equally important shared trait. However, it would be fair to say that trajectories of exclusion, oppression and abjection are equally present.

This becomes apparent in the sad story of Amuzati. In January 2003, the international media had picked up on a news item that had made its way out of the war-torn Ituri forest. "Congo rebels are eating pygmies", proclaimed The Guardian (Astill 2003), alleging that cannibalism was rife in the Ituri and that diverse 'tribal militias united by their magical beliefs and taste for human flesh' were perpetrating 'untold horrors'. Among these horrors were tales of rebel leaders feasting on the sexual organs of Pygmies and of surviving Pygmies being forced to eat the remains of their murdered kin. As this story unfolded across the media world, Amuzati was flown to Kinshasa and presented to the international media. The Washington Times (2003) report was typical. It recounted how Amuzati had managed to escape while a dozen members of his family were slaughtered. Hiding in some bushes, he watched as the rebels dismembered his six-year-old nephew and roasted the butchered body parts over an open fire. It was reported that Amuzati said, 'they even sprinkled salt on the flesh as they ate, as if cannibalism was all very natural to them.' This was pure gothic horror straight from the 'heart of darkness'; a perfect combination of defenceless Pygmies and the occult savagery of cannibalism. It was little wonder that it made global news. Perhaps equally unsurprising was relative media silence following Amuzati's retraction of his testimony at Kinshasa's Grand Hotel on 13 September 2004.

Johan Pottier (2007) has written an exemplary analysis of this extraordinary tale to which I can add little. What he makes clear is that Amuzati was drawn into highly complicated political environments and that, whatever his motivations, his actions raised the alarm with the UN. Cannibalism was a prevalent discourse within the 'pandemonium world' of the Ituri, a world in which the visible had given way to the invisible (Ibid: 239). Actual threats of cannibalism were being made to the Mbuti. As Pottier (Ibid: 238) puts it, 'as trauma-induced "tall stories" go, the factuality of cannibalism was not much to add.' The extent to which Amuzati was a political pawn or agent remains unclear, but what is certain is that for a time he played his part. He 
acted out the public role of victim and witness and he spoke the discourse of cannibalism. He reminded me of Nzito, the self-styled 'King of the Batwa' mentioned earlier(Frankland 2002). In the past, I have rather clumsily referred to actions like those of Amuzati and Nzito as being examples of 'reflective ethnicity', a way of navigating their complex interactions with a deeply unequal world, 'clinging to their own identity, while, at the same time, putting on the mask of other peoples desires for them' (Frankland 2001:251). These terms may seem to evoke echoes of the mimicry of ekila. However, the key difference is that these acts of political engagement do not cut Amuzati and Nzito off from the rest of the world. As I mentioned earlier, they are exo-social strategies of engagement that draw on language and metaphors from beyond the forest-bound world. They are attempts to exist beyond the confines of the canopy, to publicize their very real difficulties to a wider world that might notice and might even help.

According to Pottier (2007: 836-7), Turnbull misread the complexities of Mbutioutsider relations, and his obsession with Mbuti autonomy led him to see all Mbuti responses to modernity as being triumphantly defiant. That same defiance permeates Kenrick's and Lewis's understanding of Pygmy-outsider relations. Assimilation works only one way. Everything is always absorbed back into the distinctive Pygmy mentality, regardless of any imbalances and inequalities of power relations. All relations with outsiders follow this pattern and successful resistance is guaranteed. While this may be the case for Mbendjele, such certainty does not seem applicable to either the war-torn lives of Amuzati's Mbuti or the abjection of the Sua. Resistance is not always possible and not all encounters with external forces need to be premised on defiant rejection. More than that, resistance does not always work. Nzito, 'King of the Batwa', also reached out to a wider political audience when he carryied out interviews with members of the Ugandan media. While they listened and reported his words, his plea for support during the ravages of the ADF war was by and large ignored. The 'bare life' continued.

\section{CONCLUSION}

This life seems a world away from the ekila led harmony of the Mbendjele as the Bundimasoli resettlement camp is absorbed ever more swiftly into the trading centre. The complex relationships the Sua have with wide ranging networks of people cannot be reduced to the generic limitation of 'Pygmy-outsider' relations. The scope of their interactions far exceeds the mimicry as hunting strategy mode of engagement. One simple fact demonstrates this quite clearly. Young Sua men now 'marry' girls from neighbouring areas and have children with them. ${ }^{11}$ One young man, Musunguzi, has perfected his 'ganjaman' look over the last few years. ${ }^{12}$ With his weed motif bandana, dreadlocks, Rasta bracelets and spliff clamped to his lips, Musunguzi was neither mocking the videos he watched nor parodying Kampala's 'gangster' musical elite. He was making a statement easily recognizable to all the young men in the trading centre; he was a young man to be reckoned with. When the Sua celebrate Christmas it is not mere apemanship, it is a claim to a shared humanity. They are joining in, parading around the trading centre, being like everyone else by dressing up in their finest, eating meat, and drinking too much 
booze. The religious aspect is less important than the fact that they celebrate and show to the world that they still exist. The Sua are, and have had to be, very modern Pygmies. And there is nothing wrong with that.

There is one final anecdote that I would like to end with, drawn from my first research trip to Bundibugyo in 1994. A Bundibugyo bar owner who owned a generator hosted regular weekly video showings for eager customers. Often these were poor-quality tapes of Congolese musicians performing the latest kwasa kwasa dance hits, but on one evening he showed a martial arts film: another masterpiece from the extensive back catalogue of Chuck Norris. A few days later, I was taking a gentle stroll out into the countryside to try and visit the headmaster of a primary school where Nzito had been a pupil for a while. Not many white visitors came to the area in those days, and my presence was greeted with surprise. At one farmstead, the whole family came out to greet me and they took particular amusement in dragging out some very young children to observe the spectacle. The toddlers were horrified by what they saw and struggled to break free from their parents and run away. As we all laughed at the terrified children, a teenage boy came out from an adjoining house to see what all the commotion was about. Instead of fleeing in fear, he marched towards me and began to throw kung fu shapes. As with Tababa's mime, this included spinning kicks, elaborate hand gestures and stylized arm movements; and was accompanied by uproarious laughter. In contrast to the fearful flight of the children, which spoke of a distinctive Sua world, his act of mimesis eloquently expressed a sense of common humanity.

\section{ACKNOWLEDGEMENTS}

Over the years, many institutions have helped to fund my research. I would like to thank the Universities of St Andrews and London, the Economic and Social Research Council, the Horniman and Swan Funds, and also the Carnegie Trust. I would also like to thank the reviewers of this article for their useful comments and observations. In particular, I would like to thank my late father Timothy Frankland for his unconditional support of my work.

\section{BIBLIOGRAPHY}

Alnaes, K, (2009) 'Rebel Ravages in Bundibugyo, Uganda's Forgotten District' in B. Kapferer and B.E. Bertelsen (eds), Crisis of the State: War and Social Upheaval. London: Berghahn Books.

Appiah, K.A. (2000) 'Dancing with the Moon', The New York Review of Books 47 (18), 55-60.

Appiah, K.A. (2003) Thinking it Through: an introduction to contemporary philosophy. Oxford: Oxford University Press.

Appiah, K.A. (2005) The Ethics of Identity. Princeton, NJ: Princeton University Press.

Apter, A. (2007) Beyond Words: discourse and critical agency in Africa. Chicago and London: The University of Chicago Press. 
Astill, J. (2003) 'Congo rebels are eating pygmies, UN says', The Guardian, 9 January. <http://www.theguardian.com/world/2003/jan/09/congo.jamesastill>, accessed 21 September 2014.

Bahuchet, S. and H. Guillaume (1982) 'Aka-farmer relations in the northwest Congo Basin' in E. Leacock and R. Lee (eds), Politics and History in Band Societies. Cambridge University Press, Cambridge.

Bahuchet, S. 1985. Les Pygmées Aka et la Forêt Centrafricaine: Ethnologie ecologique. Paris: Selaf.

Bahuchet, S. (1993) 'L'invention des Pygmies', Cahiers d'etudes Africaines, 129 (XXXIII-I): 153-181.

Bahuchet, S. (2014) 'Cultural Diversity of African Pygmies' in B.S. Hewlett (ed), Hunter-Gatherers of the Congo Basin: Cultures, Histories and Biology of African Pygmies. New Brunswick and London: Transaction Publishers.

Ballard, C. (2006) 'Strange alliance: Pygmies in the colonial imaginary', World Archaeology, 38 (1): 133-151.

Barnard, A. (2002) 'The foraging mode of thought', Senri Ethnological Studies, 60: 524.

Bayart, J-F. (1993) The State in Africa: Politics of the Belly, M. Harper, C. \& E. Harrison (trans.). London and New York: Longman.

Beidelman, T.O. (1996) 'The King of the World in the Land of the Pygmies by Joan Mark Review', Anthropos 91 (1/3), 274-6.

Burrows, G. (1898) The Land of the Pygmies. London: C. Arthur Pearson Limited.

Casati, G. (1898) Ten Years in Equatoria. London and New York: Frederick Warne and Co.

Dowie, M. (2009) Conservation Refugees: The 100-year conflict between global conservation and native people. Cambridge, MA: MIT Press.

Frankland, S. (1999) 'Turnbull's syndrome: Romantic fascination in the rainforest' in K. Biesbrouk et al. (eds) Central African Hunter-Gatherers in a Multidisciplinary Perspective. Challenging elusiveness. Research School for Asian, African, and Amerindian Studies (CNWS), Universiteit Leiden.

Frankland, S. (2001) 'Pygmic tours', African Study Monographs, Suppl. 26, 237-256.

Frankland, S. (2002) 'The Tainted Pearl: Stories of war, tourism and development in Uganda'. PhD dissertation, University of London.

Frankland, S. (2006) 'The bulimic consumption of Pygmies: regurgitating an image of Otherness' in M. Robinson and D. Picard (eds), Tourism and Photography: The artialisation of peoples and places. Clevedon: Channel View Publications.

Grinker, R.R. (1994) Houses in the Rainforest: Ethnicity and Inequality among Farmers and Foragers in Central Africa. Berkeley \& Los Angeles: University of California Press.

Hewlett, B.S. (1996) 'Cultural Diversity among African Pygmies' in S. Kent (ed), Cultural Diversity Among Twentieth-Century Foragers: An African Perspective. Cambridge: Cambridge University Press.

Junker, W. (1892) Travels in Africa During the Years 1882-1886 \{trans. A.H. Keane). London: Chapman and Hall Ltd.

Keim, C.A. (1983) 'Long-Distance Trade and the Mangbetu', The Journal of African History 24 (1), 1-22. 
Kenrick, J. (2005) 'Equalizing processes, processes of discrimination and the forest people of Central Africa' in T. Widlok and W. Tadesse (eds), Property and Equality: Vol. 2 encapsulation, commercialization, discrimination. Oxford: Berghahn.

Kidd, C. (2009) 'Inventing the "Pygmy": Representing the "Other", presenting the "Self", History and Anthropology, 20 (4), 395-418.

Klieman, K.A. (2003) "The Pygmies were our Compass": Bantu and Batwa in the History of West Central Africa, Early Times to C.1900 C.E. Portsmouth, NH: Heinemann.

Knight, J. (2003) 'Relocated to the roadside: preliminary observations on the forest peoples of Gabon', African Study Monographs 28, 81-121.

Kretsinger, A. and Hardin R. (2003) 'Watershed, weddings and workforces: migration, sedentarization, and social change among the Baaka of southwestern Central African Republic' in African Study Monographs, Suppl. 28: 123-141

Leopold, M. (2006) 'Legacies of slavery in North-West Uganda: The story of the 'oneelevens', Africa 76 (2), 180-199.

Lewis, J. (2008) 'Ekila: blood, bodies, and egalitarian societies', Journal of the Royal Anthropological Institute 14, 397-315.

Lewis, J. (2008-9) 'Managing abundance, not chasing scarcity: the real challenge for the 21st century', Radical Anthropology 2, 11-18.

Lewis, J. (2009) 'As well as words: Congo Pygmy hunting, mimicry, and play' in R. Botha and C. Knight (eds), The Cradle of Language: Studies in the evolution of language. Oxford: Oxford University Press.

Lewis, J. (2014) 'Egalitarian Social Organization: The Case of the Mbendjele BaYaka' in B.S. Hewlett (ed), Hunter-Gatherers of the Congo Basin: Cultures, Histories and Biology of African Pygmies. New Brunswick and London: Transaction Publishers.

Moïse, R.E. (2014) "Do Pygmies Have a History?" Revisited: The Autochthonous Tradition in the History of Equatorial Africa' in B.S. Hewlett (ed), HunterGatherers of the Congo Basin: Cultures, Histories and Biology of African Pygmies. New Brunswick and London: Transaction Publishers.

Mudimbe, V. Y. (1988) The invention of Africa: Gnosis, philosophy, and the order of knowledge. Bloomington and Indianapolis: Indiana University Press.

Newell, S. (2012) The Modernity Bluff: Crime, consumption, and citizenship in Côte D'Ivoire. Chicago: University of Chicago Press.

Pottier, J. (2007) 'Rights violations, rumour, and rhetoric; making sense of cannibalism in Mambassa, Ituri (Democratic Republic of Congo), Journal of the Royal Anthropological Institute 13, 825-843.

Rupp, S. (2011) Forests of Belonging: Identities, Ethnicities, and Stereotypes in the Congo River Basin. Seattle and London: University of Washington Press.

Rupp, S. (2014) 'Multiangular Identities among Congo River Forest Peoples' in B.S. Hewlett (ed), Hunter-Gatherers of the Congo Basin: Cultures, Histories and Biology of African Pygmies. New Brunswick and London: Transaction Publishers.

Schweinfurth, G. (1874) The Heart of Africa: Three years travels and adventures in the unexplored regions of central Africa from 1868 to 1871, Vol. 2. New York: Harper \& Brothers. 
Stanley, H.M. (1890) In Darkest Africa: Or the quest, rescue and retreat of Emin Governor of Equatoria, Vol. 2. London: Sampson Low, Marston, Searle and Rivington Limited.

The Washington Times (2003) 'Cannibalism reported in Congo', 29 January. $<$ http://www.washingtontimes.com/news/2003/jan/29/20030129-0105566557r/>, accessed 21 September 2014.

Turnbull, C. (1961) The Forest People. People. London: Chatto.

Turnbull, C. (1965) Wayward Servants: The two worlds of the African Pygmies. London: Eyre \& Spottiswoode.

Turnbull, C. (1983) The Human Cycle. New York: Simon and Schuster.

Widlok, T. (2015) 'Hunter-gatherer situations'. Plenary paper presented at the Eleventh Conference on Hunting and Gathering Societies, University of Vienna, $7^{\text {th }}$ September.

1 These five groups are BaMbuti, Efe, BaAka, BaMbenzele, and Baka (Bahuchet 2014: 6)

${ }^{2}$ It is hard to give a precise figure. Different organisations have tested different members of the community at different times. No one has tested all of the Sua at the same time. Although I cannot be exact, I am certain that the percentage level is considerably higher than any figure I have ever seen for any other Pygmy group.

3 Two resettlement camps totaling twenty-one buildings were built during the project. One was at Bundimasoli while the other, Kapapepe, was a further one kilometre away on the far side of the trading centre, even further from their former forest-edge settlement. At the time of writing, only nine of the dwellings remain.

4 This resonates with Newell's (2012) ethnography of the 'modernity bluff' in Abidjan, Côte d'Ivoire, albeit in a far less deliberate and knowing sense.

5 This is a much-discussed issue. See: Bahuchet (1993), Frankland (1999, 2001, 2002, 2006), Ballard (2006) and Kidd (2009).

${ }^{6}$ In referring to the abundant forest, Lewis is deliberately creating a dichotomy with capitalist understandings of scarcity. In a generic capitalist worldview, the forest is a place of scarce resources: 'While the forest was in local people's control it was considered abundant, and actually was so. Since Euro-Americans arrived and began to perceive of forest resources as scarce, desirable and valuable, so they have become.' (Lewis 2008-9:17)

7 Gambari is responsible for one of the most infamous incidents that took place during the time of the slaving economy. 'In I877 or i878 he undertook to supply the traders with eunuch slaves, considered valuable in Arab markets. Most of his victims died from loss of blood, and the northerners had to send their own Arab agents who were more competent surgeons.' (Keim 1983:11) 
${ }^{8}$ See Bahuchet (1985) and Kretsinger and Hardin (2003) for more on 'economies of pillage'.

${ }_{9}^{9}$ There is not the space here to give a full account of the Sua's history in Uganda. The valley was a political no-man's land until the borders with Belgium were finally settled. The Sua and their Amba allies fought for their place in the valley against numerous external forces and also more local competitors. As such, their role as warriors continued to be significant for another thirty years or so, until the Semliki forest finally became fully incorporated into the British colonial system.

10 Bahuchet and Guillaume (1982) refer to the 'taming' policy adopted in the 1930 s by the French administration in the Central African Republic in relation to the Aka. This policy was an attempt to free the Aka from their subjection at the hands of their agriculturalist neighbours.

11 This is not an entirely new pattern of behavior among the Sua, although it was more common for the women to marry out.

12 The Sua's use of the word 'ganjaman' comes from their liking of the song Ganja Farmer by Marlon Asher. It was a big hit in Uganda. 